\title{
Electrochemical Performance of Lithium Iron Phosphate by Adding Graphite Nanofiber for Lithium Ion Batteries
}

\author{
Wan Lin Wang, En Mei Jin, and Hal-Bon $\mathrm{Gu}^{\dagger}$ \\ Department of Electrical Engineering, Chonnam National University, Gwangju 500-757, Korea
}

Received March 6, 2012; Revised May 23, 2012; Accepted May 29, 2012

\begin{abstract}
Olivine type $\mathrm{LiFePO}_{4}$ cathode material was synthesized by solid-state reaction method including one-step heat treatment. To improve the electrochemical characteristics, graphite nanofiber (GNF) was added into $\mathrm{LiFePO}_{4}$ cathode material. The structure and morphological performance of $\mathrm{LiFePO}_{4}$ were investigated by X-ray diffraction (XRD); and a field emission-scanning electron microscope (FE-SEM). The synthesized $\mathrm{LiFePO}_{4}$ has an olivine structure with no impurity, and the average particle size of $\mathrm{LiFePO}_{4}$ is about $200 \sim 300 \mathrm{~nm}$. With graphite nanofiber added, the discharge capacity increased from $113.43 \mathrm{mAh} / \mathrm{g}$ to $155.63 \mathrm{mAh} / \mathrm{g}$ at a current density of $0.1 \mathrm{~mA} / \mathrm{cm}^{2}$. The resistance was also significantly decreased by the added graphite nanofiber.
\end{abstract}

Keywords: $\mathrm{LiFePO}_{4}$, Solid-state, Graphite Nanofiber

\section{INTRODUCTION}

Lithium ion batteries are widely used in mobile phones, notebook computers, electronic equipment, electric vehicles and other applications. The cathode material plays a decisive role in determining the capacity and life time of the battery. Among cathode materials of lithium ion batteries, $\mathrm{LiFePO}_{4}$ with olivine structure has attracted extensive attention due to a high theoretical specific capacity $(\sim 170 \mathrm{mAh} / \mathrm{g})$, environmental friendliness, excellent thermal stability, and low cost. However, its weakness in diffusion limitation and poor electrical conductivity lead to poor electrochemical performance and makes it difficult to be used as a cathode material for commercial lithium ion batteries [1].

In recent years, many researchers have improved the electrochemical performance by coating with carbon [2-4] or preparing suitable procedures to minimize the particle size of the material [5-8], or doping supervalent metal ions to $\mathrm{Li}$ sites [9] or $\mathrm{Fe}$ sites $[10,11]$. As an active additive, graphite nanofiber (GNF)

${ }^{\dagger}$ Author to whom all correspondence should be addressed: E-mail: hbgu@chonnam.ac.kr

Copyright $@ 2012$ KIEEME. All rights reserved.

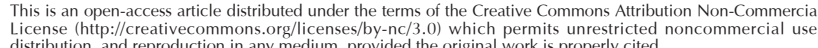
dicerse can be added to $\mathrm{LiFePO}_{4}$ cathode material. As a carbon source, it can possibly improve the electrochemical characteristics of $\mathrm{LiFePO}_{4}$ through increasing the electronic conductivity [12,13] Furthermore, various synthesis methods have been developed to prepare $\mathrm{LiFePO}_{4}$ materials. Among these methods, olivine-type $\mathrm{LiFePO}_{4}$ can be synthesized by a solid-state reaction method. The solid-state reaction is widely adopted for synthesis of pure crystalline olivine phase $\mathrm{LiFePO}_{4}$ [14].

In this study, $\mathrm{LiFePO}_{4}$ cathode material was synthesized by solid-state reaction method followed by one-step heat treatment. To improve the electrochemical characteristics, graphite nanofiber (GNF) was added to the $\mathrm{LiFePO}_{4}$ cathode material. The electrochemical characteristics of $\mathrm{LiFePO}_{4} / \mathrm{Li}$ cells were analyzed by cyclic voltammetry (CV), electrochemical impedance spectroscopy (EIS), and galvanostatic charge/discharge performance at $25^{\circ} \mathrm{C}$.

\section{EXPERIMENTS}

$\mathrm{LiFePO}_{4}$ was prepared from starting materials of $\mathrm{Li}_{2} \mathrm{CO}_{3}$ (Aldrich, 99.0\%), $\mathrm{FeC}_{2} \mathrm{O}_{4} \cdot 2 \mathrm{H}_{2} \mathrm{O}$ (Aldrich, 99.0\%), and $\mathrm{NH}_{4} \mathrm{H}_{2} \mathrm{PO}_{4}$ (Aldrich, 99.999\%). The starting materials were mixed in a molar ratio for $\mathrm{Li} / \mathrm{Fe} / \mathrm{P}=1: 1: 1$ by ball-milling with $\mathrm{N}$-methyl-2-pyrrolidone (NMP) solvent at $300 \mathrm{rpm}$ for $24 \mathrm{~h}$. After that, the obtained $\mathrm{LiFePO}_{4}$ slurry was dried at $90^{\circ} \mathrm{C}$ for $12 \mathrm{~h}$ in air. The prepared 


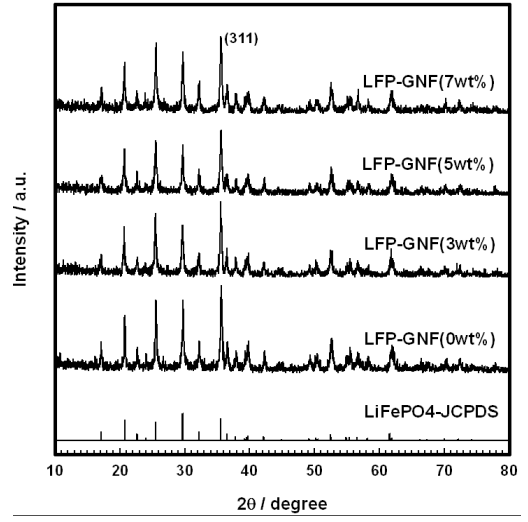

Fig. 1. XRD pattern for $\mathrm{LiFePO}_{4}$ and $\mathrm{LiFePO}_{4}$-GNF.

Table 1. The unit cell parameters of $\mathrm{LiFePO}_{4}$ and $\mathrm{LiFePO}_{4}$-GNF.

\begin{tabular}{ccccc}
\hline Specimen & $a(\mathrm{~nm})$ & $b(\mathrm{~nm})$ & $c(\mathrm{~nm})$ & $V\left(\mathrm{~nm}^{3}\right)$ \\
\hline \hline LiFePO $_{4}$ & 0.6036 & 1.0313 & 0.4708 & 0.2931 \\
LFPG(3 wt.\%) & 0.6007 & 1.0336 & 0.4690 & 0.2912 \\
LFPG(5 wt.\%) & 0.5963 & 1.0329 & 0.4722 & 0.2908 \\
LFPG(7 wt.\%) & 0.6010 & 1.0327 & 0.4696 & 0.2915 \\
\hline
\end{tabular}

$\mathrm{LiFePO}_{4}$ was pelletized then calcined at $650^{\circ} \mathrm{C}$ for $5 \mathrm{~h}$ in a nitrogen atmosphere, then ground and ball-milled with NMP at 300 rpm for $6 \mathrm{~h}$. Lastly, it was dried at $90^{\circ} \mathrm{C}$ for $24 \mathrm{~h}$ in air and ground into powder.

In order to improve the low electronic conductivity of $\mathrm{LiFePO}_{4}$, 3 wt.\%, 5 wt.\%, and 7 wt.\%, amounts of graphite nanofiber (GNF) (Diameter: $~ 300 \mathrm{~nm}$, Length: $\sim 30$ um, purity: 90\%) were respectively added to different samples.

The cathode electrode was fabricated onto Al foil using a homogeneous slurry. The slurry was prepared with $70 \mathrm{wt} . \%$ of the synthesized $\mathrm{LiFePO}_{4}$ (LFP) or $\mathrm{LiFePO}_{4}$-GNF (LFPG), $25 \mathrm{wt} . \%$ carbon black (SP-270), and 5 wt.\% polyvinylidene di-fluoride (PVDF) binder, which was dissolved in NMP solvent. The slurry was spread onto the $\mathrm{Al}$ foil. After drying at $90^{\circ} \mathrm{C}$ and being roll pressed, the area of the coated cathode electrode was cut to $2 \times 2$ $\mathrm{cm}^{2}$. The electrodes were dried in a vacuum oven under a vacuum pressure of 760 Torr at $110^{\circ} \mathrm{C}$ for $24 \mathrm{~h}$.

The LFP/Li cell and LFPG/Li cells were assembled in an argon filled glove box using lithium metal foil as the anode electrode. Polypropylene film (Celgard 2500) was used as the separator and a solution of $1 \mathrm{M} \mathrm{LiPF}_{6}$ in ethylene carbonate (EC) and dimethyl carbonate (DMC) (1:1 in volume) was used as the electrolyte.

The samples were charged and discharged over a voltage range of 2.5-4.0 V using a current density of $0.1 \mathrm{~mA} / \mathrm{cm}^{2}$ for both processes by WBCS-3000 8ch substation. Cyclic voltammetry (CV) measurements were performed using an IM6 instrument at a $0.1 \mathrm{mV} / \mathrm{s}$ scanning rate. AC impedance measurement was performed over the frequency range of $2 \mathrm{MHz}$ to $10 \mathrm{mHz}$.

\section{RESULTS AND DISCUSSION}

Figure 1 shows the XRD pattern of the $\mathrm{LiFePO}_{4}$ and $\mathrm{LiFePO}_{4}{ }^{-}$ GNF samples. All the patterns can be indexed to a single-phase material having an orthorhombic olivine-type structure with a space group of Pnma, which is almost the same as the one that is listed in the X-ray diffraction data file (JCPDS card). No impurities such as $\mathrm{Fe}_{2} \mathrm{O}_{3}, \mathrm{Li}_{3} \mathrm{Fe}_{2}\left(\mathrm{PO}_{4}\right)_{3}$ or $\mathrm{Li}_{3} \mathrm{PO}_{4}$ were found in the LiFe$\mathrm{PO}_{4}$ or $\mathrm{LiFePO}_{4}-\mathrm{GNF}$ powders, as indicated by the lack of other peaks found in the main peaks of the $\mathrm{LiFePO}_{4}$. There was also no (a)

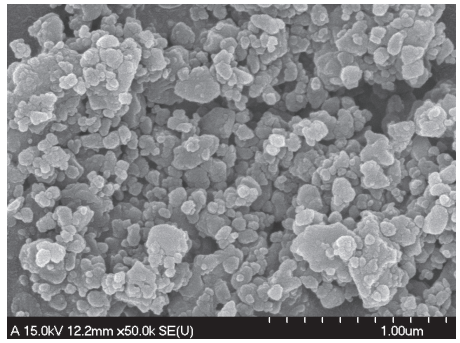

(b)

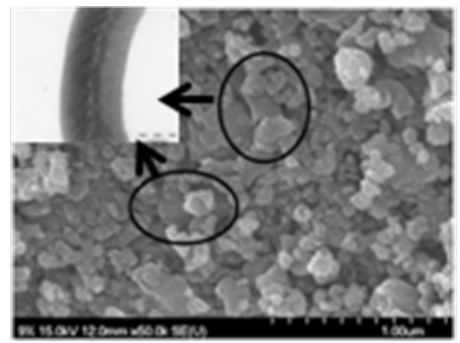

Fig. 2. FE-SEM image of $\mathrm{LiFePO}_{4}$ (a) and $\mathrm{LiFePO}_{4}$-GNF (b).

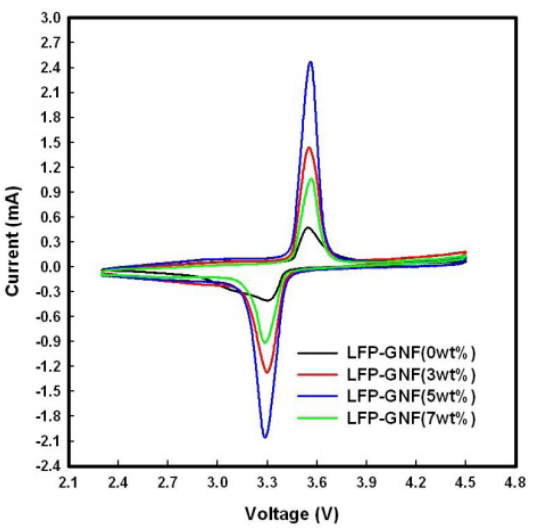

Fig. 3. 50th Cyclic voltammogram of LFP/Li cell and LFPG/Li cells at a scan rate of $0.1 \mathrm{mV} / \mathrm{s}$.

evidence for crystalline carbon, nor were there any amorphous peaks present. This is undoubtedly due to the small amount of carbon present and the thinness of the layer on the $\mathrm{LiFePO}_{4}$ and $\mathrm{LiFePO}_{4}$-GNF.

The unit cell parameters of the prepared samples are given in Table 1, which was calculated in the XRD analysis. The cell parameters for the $\mathrm{LiFePO}_{4}$ sample are $a=0.6036 \mathrm{~nm}, b=1.0313$ $\mathrm{nm}, c=0.4708 \mathrm{~nm}$, and the unit cell volume is $V=0.2931 \mathrm{~nm}^{3}$. The unit cell parameters of $\mathrm{LiFePO}_{4}-\mathrm{GNF}(5 \mathrm{wt} . \%)$ are $a=0.5963 \mathrm{~nm}$, $b=1.0329 \mathrm{~nm}, c=0.4722 \mathrm{~nm}$, and $V=0.2908 \mathrm{~nm}^{3}$. From Table 1, it can be seen that the lattice parameter changes slightly with added GNF. Meanwhile, we can clearly see from the phenomenon in Fig. 1 that the diffraction peaks (311) of the samples gradually shift right when GNF is added, which means the unit cell volume minimizes gradually according to the Prague equation. The volume contraction of the added samples might be due to the coexistence of lithium ion vacancies caused by added GNF [1].

FE-SEM was tested to confirm the particle size and image of $\mathrm{LiFePO}_{4}$ and $\mathrm{LiFePO}_{4}$-GNF samples. Figure 2 show the FE-SEM images of $\mathrm{LiFePO}_{4}$ and $\mathrm{LiFePO}_{4}$-GNF. The figure shows that the particle size of all the samples is about 200 300 nm. For $\mathrm{LiFePO}_{4}$, small particle size is important for enhancing the electrochemical properties [15]. In particles with a small diameter, the lithium ions may diffuse over smaller distances between the surfaces and center during lithium intercalation and de-intercalation. And as 


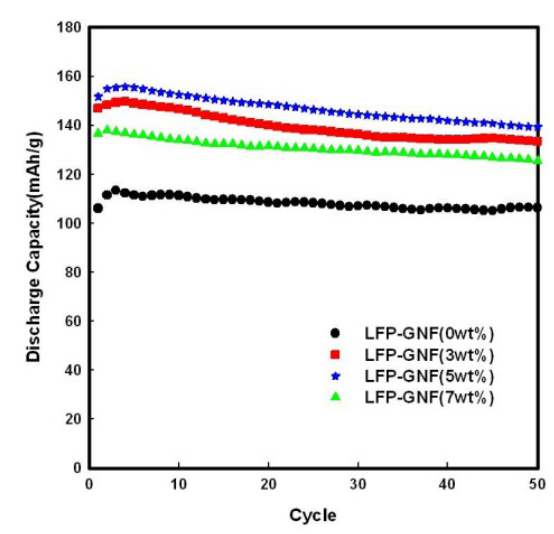

Fig. 4. Discharge capacity of the LFP/Li cell and LFPG/Li cells.

(a)

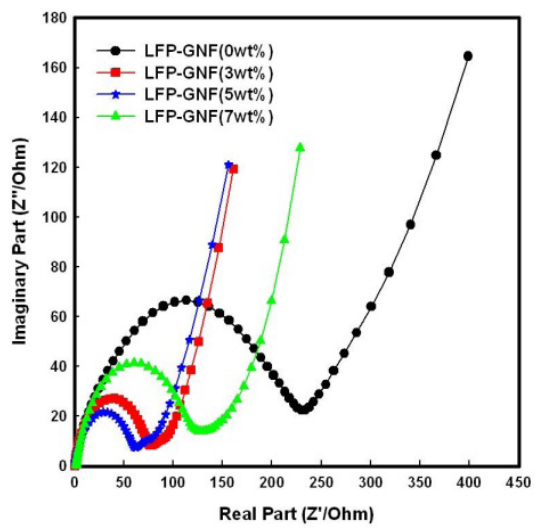

(b)

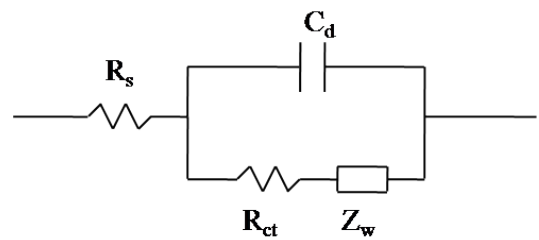

Fig. 5. 10th impedance spectra of LFP/Li cell and LFPG/Li cells at $25^{\circ} \mathrm{C}$ (a) and Equivalent circuit of the impedance spectra (b).

shown in Fig. 2(b), the typical morphology of tubular graphite nanofiber was observed (the image of the graphite nanofiber is shown in the inset, which is on the left). It can be seen that the $\mathrm{LiFePO}_{4}$ particles are homogenously adhered to the surface of the graphite nanofiber. The bridging graphite nanofiber can form an effective conducting network. At the same time, a porous structure between $\mathrm{LiFePO}_{4}$ and graphite nanofiber was formed by the random hybrid composite, which can facilitate the penetration of the electrolyte to the surface of active materials. As a result, $\mathrm{LiFePO}_{4}$-GNF has a superior rate capability and higher reversible capacities in comparison with the $\mathrm{LiFePO}_{4}$ [13].

Figure 3 shows cyclic voltammograms of the LFP/Li cell and LFPG/Li cells taken at a scan rate of $0.1 \mathrm{mV} / \mathrm{s}$, between $2.3 \sim 4.5$ $\mathrm{V}$ at the 50th cycle. As for $\mathrm{CV}$, the voltage difference between the oxidation peak and reduction peak is an important parameter to evaluate the electrochemical reaction reversibility [16]. All of the cells' oxidation and reduction peaks appear at about $3.6 \mathrm{~V}$ and $3.3 \mathrm{~V}$. The voltage difference between the oxidation and reduction peak is $0.3 \mathrm{~V}$. Furthermore, the CV of the LFPG/Li cells shows more symmetry and a sharper shape of oxidation and reduction peaks, which indicates better electrochemical activity [17]. Particular, the intensity of the LFPG (5 wt.\%) cell peak is highest. The well-defined peaks and smaller potential peak separation

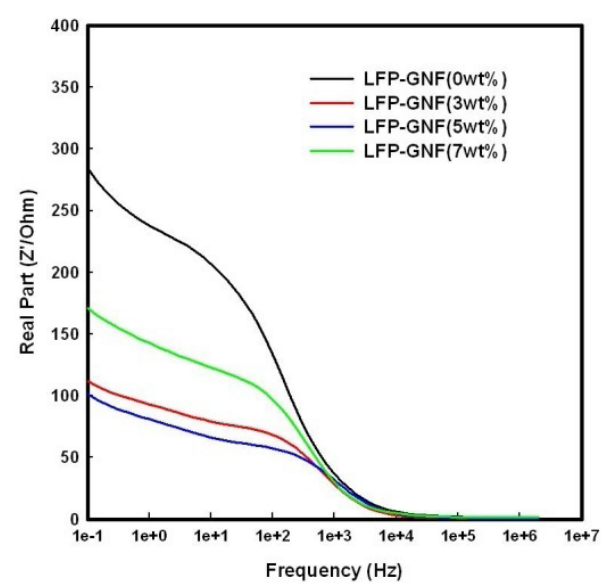

Fig. 6. Bode diagram of LFP/Li cell and LFPG/Li cells at $25^{\circ} \mathrm{C}$

indicate higher electrochemical reactivity and lower ohmic resistance for the LFPG(5 wt.\%)/Li cell.

Figure 4 shows the discharge curves of the LFP/Li cell and LFPG/Li cells at a current density of $0.1 \mathrm{~mA} / \mathrm{cm}^{2}$. The initial discharge capacity of the LFP/Li cell is $106.03 \mathrm{mAh} / \mathrm{g}$. The highest capacity, which appears in the 3rd cycle, is $113.43 \mathrm{mAh} / \mathrm{g}$. After 50 cycles, the discharge capacity is retained $106.32 \mathrm{mAh} / \mathrm{g}$. To improve the capacity of $\mathrm{LiFePO}_{4}$, graphite nanofiber was added in amounts of 3 wt.\%, 5 wt.\%, 7 wt.\% to $\mathrm{LiFePO}_{4}$. The initial discharge capacity of LFPG(5 wt.\%)/Li cell is $151.73 \mathrm{mAh} / \mathrm{g}$. The highest capacity is achieved in the 4 th cycle at $155.63 \mathrm{mAh} / \mathrm{g}$. After 50 cycles, the discharge capacity is retained at $139.45 \mathrm{mAh} /$ g. These results are the same as the FE-SEM and CV test results, which were analyzed above. In addition, compared to the LFP/Li cell, the discharge capacity of the LFPG(5 wt.\%)/Li cell increased by $37.20 \%$.

Figure 5(a) shows the impedance performance of the LFP/ $\mathrm{Li}$ and LFPG/Li cells at $25^{\circ} \mathrm{C}$. The frequency range was from 2 $\mathrm{MHz}$ to $10 \mathrm{mHz}$, and amplitude was $5 \mathrm{mV}$. The AC impedance response of the cells consisted of a broad semicircle in the highmiddle frequency region and a sloping line in the low frequency region. The impedance spectra can be interpreted on the basis of an equivalent circuit with ohmic resistance (Rs), charge-transfer resistance (Rct), capacitance of the double layer (Cd), and Warburg impedance (Zw), as indicated in Fig. 5(b). It has been recognized that the high-middle frequency semicircles might correspond to the charge-transfer impedance that resulted from the electrochemical reaction at the electrode and electrolyte interface. The sloping line in the low frequency region is attributed to the Warburg impedance, which is associated with lithium ion diffusion in the $\mathrm{LiFePO}_{4}$ electrode. In the 10th cycle, the resistance of the LFP/Li cell is $280 \Omega$, and the resistance of the LFPG(5 wt.\%)/Li cell is $100 \Omega$, which are shown in figure 3.6. It is obvious that the resistance decreased after adding the graphite nanofibers.

\section{CONCLUSIONS}

In this research, $\mathrm{LiFePO}_{4}$ cathode material with olivine structure was synthesized by solid-state method followed by one-step heat treatment. To improve the electrochemical characteristics of $\mathrm{LiFePO}_{4}$, graphite nanofiber was added, and the morphology properties were analyzed. During the lithium-ion intercalation and de-intercalation processes, the lithium-ion diffusion coefficient was boosted after adding GNF. Impedance results show that the conductivity was enhanced by the added GNF, because 
the charge-transfer resistance was significantly reduced. Cyclic voltammetry results indicated that the electrode redox reaction reversibility was excellent due to adding GNF. The LFPG(5 wt.\%)/ Li cell exhibited superior high discharge capacity and cycling stability at $25^{\circ} \mathrm{C}$. The results demonstrate that a feasible route of adding GNF by solid-state reaction has been offered.

\section{ACKNOWLEDGMENTS}

The following are results of a study on the "Human Resource Development Center for Economic Region Leading Industry" Project, supported by the Ministry of Education, Science \& Technology (MEST) and the National Research Foundation of Korea (NRF).

\section{REFERENCES}

[1] Hu Guo-rong, GAO Xu-guang, PENG Zhong-dong, DU Ke, TAN Xian-yan, LIU Yan-jun, Trans Nonferrous Met Soc. China. 17 (2007) 296-300 [DOI: http://dx.doi.org/10.1016/S10036326(07)60088-0].

[2] HU G R, GAO X G, PENG Z D, CHEN Z Y, TAN X Y, YU XY, Trans Nonferrous Met Soc. China. (2005), 15(4): 795-798

[3] MYUNG S T, KOMABA S, HIROSAKI N, YASHIRO H, KUMAGAI N. Electrochimica Acta, 2004 49(24): 4213-4222 [DOI: http:// dx.doi.org/10.1016/j.electacta.2004.04.016].

[4] BAKER J, SAIDI M Y, SWOYER J. Electrochem SolidState Lett, 2003 6(3): A53-A55 [DOI: http://dx.doi. org/10.1201/9780203913321.ch15].

[5] YANG S F, ZAVALIJ P Y, WHITTINGGHAM M S. Electrochem Commun, 2001, 3(9): 505-508 [DOI: http://dx.doi.org/10.1016/ S1388-2481(01)00200-4]

[6] PARK K S, KANG K T, LEE S B, KIM G Y, PARK Y J, KIM H G. Ma- terials Research Bulletin, 2004, 39(12): 1803-1810 [DOI: http:// dx.doi.org/10.1016/j.materresbull.2004.07.003].

[7] YAMADA A, CHUNG S C, HINOKUMA K. J Electrochem Soc, 2001, 148(3): A224-A229 [DOI: http://dx.doi. org/10.1149/1.13482 57]

[8] CHO T H, CHUNG H. J Power Sources, 2004, 133(2): 272-276 [DOI: http://dx.doi.org/10.1016/j.jpowsour.2004.02.015].

[9] CHUNG S Y, BLOCKING J T, CHIANG Y M. Nature Mater, 2002, 2: 123-128 [DOI: http://dx.doi.org/10.1038/nmat732].

[10] MI C H, ZHANG X G, ZHAO X B, LI H L. Materials Science \& Engineering, 2006, 129: 8-13 [DOI: http://dx.doi.org/10.1016/ j.mseb.2005.11.015].

[11] SLI G H, KUDO Y, LIU K Y, AZUMA H, TOHDA M. J Electrochem Soc, 2002, 149(11): A1414-A1418 [DOI: http://dx.doi. org/10.1149/1.1510768].

[12] Xinlu Li, Feiyu Kang, Xinde Bai, Wanci Shen, Electrochemistry Communications 9 (2007) 663-666 [DOI: http://dx.doi. org/10.1016/j.elecom.2006.10.050].

[13] Li Wang, Haibo Wang, Zhihong Liu, Chen Xiao, Shanmu Dong, Pengxian Han, Zhongyi Zhang, Xiaoying Zhang, Caifeng Bi, Guanglei Cui. Solid State Ionics 181 (2010) 1685-1689 [DOI: http://dx.doi.org/10.1016/j.elecom.2006.10.050].

[14] Hee-Cheol Kang, Dae-Kyoo Jun, Bo Jin, En Mei Jin, KyungHee Park, Hal-Bon Gu, Ki-Won Kim, Journal of Power Sources 179 (2008) 340-346 [DOI: http://dx.doi.org/10.1016/ j.jpowsour.2007.12.093].

[15] A. K. Padhi, K. S. Nanjundaswamy, J. B. Goodenough, J. Electrochem. Soc. 144 (1997) 1188 [DOI: http://dx.doi. org/10.1149/1.1837571].

[16] J. F. Ni, H. H. Zhou, J. T. Chen, X. X. Zhang, Mater. Lett. 59 (2005) 2361 [DOI: http://dx.doi.org/10.1002/chin.200544013].

[17] Atef Y. Shenouda, Hua K. Liu. Journal of Alloys and Compounds 477 (2009) 498-503 [DOI: http://dx.doi.org/10.1016/ j.jallcom.2008.10.077] 